\title{
Quality Investing in Indonesian Stock Market
}

\author{
Kautsar Primadi Nurahmad ${ }^{1, *}$ Irwan Adi Ekaputra ${ }^{1, *}$
}

\author{
${ }^{1}$ Department of Management, Universitas Indonesia, Indonesia \\ *Corresponding author.Email: kautsar.nurahmad@gmail.com, irwan.adi@ui.ac.id
}

\begin{abstract}
This research examines whether quality investing in Indonesian stock market could generate abnormal return. The quality score is calculated from following criteria: profitability, growth, and safety. From the quality score, we construct portfolio of highest quality stocks, lowest quality (junk) stocks, and based on quality minus junk investment strategy which long quality portfolio and short junk portfolio. Using stocks listed at the Indonesia Stock Exchange from 2009 until 2019, we run regression test with Ordinary Least Square method and compute alphas with respect to single index model, three factor model, and four factor model to find whether constructed portfolio can provide abnormal return. This research find that quality portfolio can consistently earn significant, positive abnormal return of $1.1 \%$ to $1.2 \%$. In contrary, this research does not find that junk and quality minus junk portfolio could prove significant abnormal return. These findings can give evidence that investor should consider stocks with high quality to achieve abnormal return when investing in the Indonesian stock market and avoid stocks with low quality.
\end{abstract}

Keywords: Quality Investing, Profitability, Growth, Safety, Abnormal Return.

\section{INTRODUCTION}

Investors and researchers were trying to find methodologies to beat the market performance and earns return premium. They in turn found that Efficient Market Hypothesis is not working as defined by Kendall (1953). There are some market anomalies that could be exploited to gain abnormal return. Banz (1981) discovered that there is a negative relationship between the market value of a firm's equity and the securities returns. Jegadeesh and Titman (1993) discovered that methods including buying well-performing stocks and selling poorlyperforming stocks yield a large positive historical return. Graham and Dodd (2009) realized that investing in value stocks could beats the market. Piotroski (2000) underlines that high book-to-market investors gain an annual premium for at least $7.5 \%$.

There are emerging numbers of research that examine quality of stock issuer as anomalies that provide riskadjusted excess return. The subject of the research is important because there is no well accepted consensus to define quality for stocks. Hsu, Kalesnik, and Kose (2019) explained quality investment criteria to defines companies with good financial quality.

A group of research find that investing in high quality stock will provide significant positive return while investing in low quality stock will provide significant negative excess return. According to Kozlov and Petajisto (2013), going long on stocks with high earning quality and short on companies with low earning quality might offer a high Sharpe ratio. Gallagher, Gardner, Schmidt, and Walter (2014) has found that stock with good quality will provides abnormal return compared to lower quality stocks. Asness, Frazzini, and Pedersen (2019) found that in the United States and 24 developed market, long stocks with a high quality score and short stocks with a bad quality score will generate a substantial abnormal return.

In the awakening of research developments summarized above, this research intended to examine quality investing strategy in Indonesian market. Indonesian capital market has growth rapidly for the last 10 years. The stock return on the Indonesia Stock Exchange (IDX) from 2008 to 2019 earns a very high record. The Jakarta Composite Index (JCI) which is a composite index that summarizes the price performance of all shares listed on the IDX, recording an increase of $148.57 \%$, from $1,355.408$ at the end of 2008 to $6,299.539$ at the end of 2019. The growth has been proven well by numbers of market size indicators as well as number of market participants. This numbers of fact makes Indonesian capital market is an interesting objective for this study.

On 2019, IDX launched new stock index relating to quality investing called IDX Quality30 Index. They select quality stocks with high Return on Equity (ROE), low Debt to Equity Ratio (DER), and low Volatility of Earning per Share (EPS) growth. This also shown that the market side already embrace the needs of quality defined benchmark. Then, the question that arise: is that quality strategy investing will provide significant positive abnormal return in Indonesian capital market? 
This research is consistent to the previous research that quality stocks could earns significant abnormal return. In contrary junk stocks could not earn significant abnormal return. However, we are unable to found that long quality stocks and short junk stocks will generate a substantial abnormal return. Moreover, this research complements the literature by giving the same quality portfolio evidence in Indonesia as developing market which differ to previous study that mainly focus on developed market. This research will be beneficial to fund managers and retail investors to become considerations building their investment strategy.

The article is segmented as follows: the next section will explore previous studies regarding quality stocks, continued by sections that discussed methodology, followed by results section, and closed with conclusion section.

\section{LITERATURE REVIEW}

The early literatures related to the definition of quality investing are very segmented and appear disconnected. However, all of these are examining outperformance of variables that define high-quality stocks in this research.

Novy-Marx (2012, 2013) documented those stocks with high profitability outperform market. Black et al. (1972) and Frazzini and Pedersen (2014) found that stocks, bonds, credit, and futures with low beta will provide abnormal return. George and Hwang (2010) and Penman et al. (2007) found low leverage firms will provide abnormal return. Altman (1968), Ohlson (1980), and Campbell et al. (2008) find firms with low credit risk will outperform firms with high credit risk. Sloan (1996) and Richardson et al. (2005) found that companies with higher accruals will have low stock return performance and lower than expectations earning report compared to other companies with lower accruals.

Recent literatures are trying to combine all this separate definition of quality. Asness, Frazzini, and Pedersen (2019) explain stock quality as criteria that investors willing to buy in more expensive price. From Gordon's Growth Model they elaborate the definition into three definitions of quality. The first one is profitability, second is growth, and the third is safety.

Profitability comes in because profitable companies will attract investors to buy the stocks resulting in expensive stock price. Numbers of research related to profitability also have the biggest population. Fama and French (2015, 2016), Novy-Marx (2013), Hou, Xue, and Zhang (2015), and Ball et al. (2015) are supporting that profitability is in line with positive stock premium.

Growth is measuring how the profitability changes for the last five years. Studies that supporting this definition is Mohanram (2005) revealed that businesses with high growth outperform those with low growth.

In Asness, Frazzini, and Pedersen (2019), high price observed in number of stocks with high quality, regardless quality has low explanatory power on prices. They discover that high-quality companies outperform junk companies in terms of excess returns. Then they constructed a Quality minus Junk (QMJ) strategy by buying the quality stocks and selling the junk stocks. Applying this strategy with big and small stocks, the QMJ provide abnormal return in US and 23 developed markets.

All and all, a large body but segmented literature has discussed how defined quality in asset selection. but none of them are having emerging and developing market as object of their research. This study fills this gap by determining the does the same evidence could be achieved by applying same methodology in developing market such as Indonesia. Therefore, the hypothesis of this study is as follows:

H1: Quality investing in Indonesian stock market will provide abnormal return.

\section{METHODOLOGY}

Using all listed stock in Indonesia Stock Exchange (IDX) from 2009 until 2019 we applied similar method in Asness, Frazzini, and Pedersen (2019) in calculating quality score. We decide to run similar method because they conclude all methods to measure quality from various research. We exclude stocks in financial sector because of non-consistent financial report post such as leverage, and accruals as suggested by Taylor and Wong (2012).

The quality defined from three criteria: Profitability, Growth, and Safety. We create a high-quality portfolio with $30 \%$ of the highest quality score (Quality portfolio) and a low-quality portfolio with $30 \%$ of the lowest quality score (Junk portfolio). Furthermore, we construct a quality minus junk (QMJ) portfolio, which is an investing strategy that consists of long high-quality companies and short low-quality companies.

We run regression test with Ordinary Least Square method and compute alphas with respect to single index model, three factor model by Fama and French, and four factor model by Carhart to find whether quality investing could provide abnormal return. We also construct market return portfolio (M), company size portfolio (SMB), book to market value portfolio (HML), and momentum return portfolio (UMD) to become explanatory variables.

\subsection{Quality Score}

The methodology uses to obtain quality score use the same approach from Asness, Frazzini, and Pedersen 
(2019). The three composite proxies are: profitability, growth, and safety. The quality z-score is calculated as follows:

$$
\text { Quality }=\text { z (Profitability }+ \text { Growth }+ \text { Safety })
$$

The quality z-score calculated in Equation (1) is the average $\mathrm{z}$-score of the three categories. To combine the different ratios appropriately, the methodology of z-score is used. The $\mathrm{z}$-score is calculated as follow:

$$
\mathrm{Z}=(\mathrm{x}-\mu) / \sigma
$$

In Equation (2), $\mathrm{Z}$ represents $\mathrm{Z}$-score, $\mathrm{x}$ represents observed variable, $\mu$ represents mean of observed variable, $\sigma$ represents standard deviation of observed variable.

After we calculate the quality z-score of all stocks, $30 \%$ highest quality score is considered as Quality stocks, and $30 \%$ lowest quality score is considered as Junk stocks.

\subsubsection{Profitability}

Components to calculate Profitability category consist of gross profit over assets (GPA), return on equity (ROE), return on assets (ROA), cash flow over assets (CFA), gross margin (GM), and accruals (ACR). The ratios are the higher the better except is the ACR, where a lower value is better. Finally, the single values are averaged out into one profitability z-score:

$$
\begin{gathered}
\text { Profitability }=\mathrm{z}\left(\mathrm{z}_{\mathrm{gpa}}+\mathrm{z}_{\mathrm{roe}}+\mathrm{z}_{\mathrm{roa}}+\mathrm{z}_{\mathrm{cfa}}\right. \\
\left.+\mathrm{z}_{\mathrm{gm}}+\mathrm{z}_{\mathrm{acr}}\right)
\end{gathered}
$$

\subsubsection{Growth}

To calculate Growth component, we measure the five-year prior growth rate in all components of profitability category exclude accruals. To calculate growth rate, we use simple growth formula as follows:

Growth Rate $=\frac{x_{t}-x_{t-5}}{x_{t-5}}$

The Growth z-score is computed as follows:

$$
\begin{aligned}
\text { Growth }= & \mathrm{z}\left(\mathrm{z}_{\Delta \mathrm{gpa}}+\mathrm{z}_{\Delta \text { roe }}+\mathrm{z}_{\Delta \text { roa }}\right. \\
& \left.+\mathrm{z}_{\Delta \mathrm{cfa}}+\mathrm{z}_{\Delta \mathrm{gm}}\right)
\end{aligned}
$$

\subsubsection{Safety}

Components to calculate Safety category consist of beta (BET), leverage (LEV), Altman's score (Z) and quarterly volatility of ROE (REV). Thus, the Safety zscore formula as follows:

$$
\text { Safety }=\mathrm{z}\left(\mathrm{z}_{\mathrm{bet}}+\mathrm{z}_{\mathrm{lev}}+\mathrm{z}_{\mathrm{z}}+\mathrm{z}_{\mathrm{rev}}\right)
$$

\subsection{Quality Investing Portfolios}

To find the abnormal return for quality investing, we create three portfolios based on quality score. The first portfolio called Quality Portfolio that consist of 50\% quality stocks from big-size company and $50 \%$ quality stocks from small-size company defined as follows:

$$
\text { Quality }=\frac{(\mathrm{SQ}+\mathrm{BQ})}{2}
$$

In the Equation (7), SQ represents small-quality portfolio monthly return and $\mathrm{BQ}$ represents big-quality portfolio monthly return.

To observe the performance of Junk Portfolio, we construct the second portfolio called Junk Portfolio that consist of $50 \%$ junk stocks from big-size company and $50 \%$ junk stocks from small-size company defined as follows:

$$
\text { Junk }=\frac{(\mathrm{SJ}+\mathrm{BJ})}{2}
$$

In the Equation (8), SJ represents small-junk portfolio monthly return and BJ represents big-junk portfolio monthly return.

The third portfolio constructed based on quality minus junk (QMJ) investment strategy which defined as follows:

$$
\mathrm{QMJ}=\frac{(\mathrm{SQ}+\mathrm{BQ})}{2}-\frac{(\mathrm{SJ}+\mathrm{BJ})}{2}
$$

On all portfolios, stocks are sorted by size and then by quality score. Using the same approach with Fama and French (1993) to assign big and small factor which consider top half of total market capitalization considered as big size, while bottom half of total market capitalization considered as small size. All portfolio used equal weighted and rebalanced every end of June. 


\subsection{Abnormal Return Test}

To observe abnormal return from three constructed portfolios (Quality, Junk, and QMJ), we will compute alpha with respect to single index model, three factor model by Fama and French, and four factor model by Carhart. These alphas are the intercepts from each regression models.

$$
\begin{aligned}
& E\left(R P_{t}\right)-R F_{t}=\alpha+\beta_{M} E\left[M K T_{t}\right] \\
& E\left(R P_{t}\right)-R F_{t}=\alpha+\beta_{M} E\left[M K T_{t}\right] \\
& +\beta_{\mathrm{SMB}} \mathrm{E}\left[\mathrm{SMB}_{\mathrm{t}}\right] \\
& +\beta_{\mathrm{HML}} \mathrm{E}\left[\mathrm{HML}_{\mathrm{t}}\right] \\
& E\left(R P_{t}\right)-R F_{t}=\alpha+\beta_{M} E\left[M T_{t}\right] \\
& +\beta_{\mathrm{SMB}} \mathrm{E}\left[\mathrm{SMB}_{\mathrm{t}}\right] \\
& +\beta_{\mathrm{HML}} \mathrm{E}\left[\mathrm{HML}_{\mathrm{t}}\right] \\
& +\beta_{\mathrm{UMD}} \mathrm{E}\left[\mathrm{UMD}_{\mathrm{t}}\right]
\end{aligned}
$$

Equation (10) is single index model from Sharpe (1963), Equation (11) is three factor model from Fama and French (1993), and Equation (12) is four factor model from Carhart (1997). $\mathrm{E}\left(\mathrm{RP}_{\mathrm{t}}\right)$ represents expected return of portfolio (Quality, Junk, and $\mathrm{QMJ}$ ), $\mathrm{RF}_{\mathrm{t}}$ represents risk free rate, $\alpha$ represents intercept, $\beta$ represents slope for each factor, MKT represents market excess return, SMB represent size factor (small minus big market capitalization company), HML represents value factor (high minus low book to market), and UMD represents momentum factor (winners minus loosers).

MKT calculated by subtract Jakarta Composite monthly return as market return with yield of 1-month benchmark Indonesian government bond as risk free rate.

Meanwhile SMB, HML, and UMD calculated as follows:

$$
\begin{aligned}
& \mathrm{SMB}=\frac{(\mathrm{SH}+\mathrm{SN}+\mathrm{SL})}{3}-\frac{(\mathrm{BH}+\mathrm{BN}+\mathrm{BL})}{3} \\
& \mathrm{HML}=\frac{(\mathrm{SH}+\mathrm{BH})}{2}-\frac{(\mathrm{SL}+\mathrm{BL})}{2} \\
& \mathrm{UMD}=\frac{(\mathrm{SU}+\mathrm{BU})}{2}-\frac{(\mathrm{SD}+\mathrm{BD})}{2}
\end{aligned}
$$

In the Equation (13) and (14), SH represents small market capitalization and high book to market portfolio monthly return, SN represents small market capitalization and mid book to market portfolio monthly return, SL represents small market capitalization and low book to market portfolio monthly return, $\mathrm{BH}$ represents big market capitalization and high book to market portfolio monthly return, BM represents big market capitalization and mid book to market portfolio monthly return, BL represents big market capitalization and low book to market portfolio monthly return.

To assign size factor, we consider top half of total market capitalization considered as big market capitalization stocks, while bottom half of total market capitalization considered as small market capitalization stocks. To assign value factor, we consider top $30 \%$ book to market as high stocks, bottom $30 \%$ book to market as low stocks, and the rest as mid stocks.

In the Equation (15), SU represents small market capitalization and winner portfolio monthly return, BU represents big market capitalization and winner portfolio monthly return, SL represents small market capitalization and loosers portfolio monthly return, and BL represents big market capitalization and loosers portfolio monthly return.

To assign momentum factor, we consider $30 \%$ stocks with highest 11-month return with 1-month lag as winner stocks and $30 \%$ stocks with lowest 11-month return with 1-month lag as loosers stocks.

\section{RESULT AND ANALYSIS}

Table 1 presents the result of regression of quality, junk, and quality minus junk portfolio and reveal the estimated alpha on each model.

In single index model, three factor model by Fama and French, and four factor model by Carhart, quality portfolio consistently delivers abnormal returns. This can be seen from the quality portfolio is having significant positive alpha of $1.1 \%-1.2 \%$. Meanwhile, junk portfolio and quality minus junk also have positive but not significant alpha. Therefore, junk portfolio and quality minus junk portfolio cannot generate abnormal returns.

Inability of quality minus junk from delivering positive and significant abnormal return explained by the disincentive for short selling regulation from the market regulator. As stated in Regulation of Indonesia Financial Service Authority (Otoritas Jasa Keuangan) Number 55 Year 2020 that short selling should be done at one price tick above market price, and one should disclose short selling motive.

The market excess return (MKT) shows how much market excess return influence the excess return of each portfolio. We could observe that MKT has positive and significant influence on both quality and junk portfolio. One explanation is that this correlation built since portfolio construction of quality and junk portfolio consist of big stocks. Because of Jakarta Composite Index is market capitalization weighted stock index, big stocks will become main driver of index movement. 
Table 1. Regression Result

\begin{tabular}{|l|c|c|c|}
\hline & \multicolumn{2}{|c|}{ Portfolio } & Quality minus Junk \\
\hline Single Index alpha & Quality & Junk & 0.002 \\
& 0.011 & 0.003 & $(0.6506)$ \\
\hline Three factor alpha & $(3.4409)^{\star \star \star}$ & $(0.7920)$ & 0.004 \\
& 0.012 & 0.003 & $(1.147)$ \\
\hline Four factor alpha & $(3.689)^{\star \star \star}$ & $(0.814)$ & 0.003 \\
& 0.012 & 0.004 & $(0.928)$ \\
\hline MKT Four factor Model & $(3.633)^{\star \star \star}$ & $(0.983)$ & 0.128 \\
& 1.382 & 1.294 & $(0.503)$ \\
\hline SMB Four factor Model & $(4.900)^{\star \star \star}$ & $(3.701)^{\star \star \star}$ & -0.103 \\
& -0.170 & -0.060 & $(-0.964)$ \\
\hline HML Four factor Model & $(-1.423)$ & $(-0.403)$ & -0.264 \\
& -0.016 & 0.249 & $(-3.643)^{\star \star \star}$ \\
\hline UMD Four factor Model & $(-0.200)$ & $(2.499)^{\star \star}$ & 0.227 \\
& 0.026 & -0.201 & $(2.927)^{\star \star \star}$ \\
\hline
\end{tabular}

${ }^{* \star \star} p<0.01 ;{ }^{* \star} p<0.05 ;{ }^{*} p<0.1$

The size factor (SMB) shows how much the strategy of long stock with small market capitalization and short stock with large market capitalization (small minus big) has influence the excess return of each portfolio. The results of tests carried out on the entire portfolio consistently produced a negative and insignificant SMB coefficient. This shows that there is no influence of the size factor on the quality, junk, and quality minus junk portfolios.

The book to market factor (HML) shows how much strategy of long stocks with a high book to market and short stocks with a low book to market (high minus low) has influence on the excess return of each portfolio. Junk portfolio has positive and significant influence from HML coefficient. This shows that there is an influence of book to market factor on the junk portfolio.

Meanwhile, the quality minus junk portfolio has a negative and significant HML coefficient. This result is in line with the research of Asness, Frazzini, and Pedersen (2018) which explains that this result occurs because of the inverse relationship between the QMJ portfolio that purchases high quality stocks which tend to have relatively expensive prices, while the book to market factor is obtained by buying stocks with high book to market or low-price valuations.

The momentum factor (UMD) shows how much the strategy of long winner stocks and short looser stocks has influence on the excess return of each portfolio. The results of the Carhart Four Factor Model testing carried out on a quality minus junk portfolio produced a positive and significant UMD coefficient. This shows that there is an influence of the momentum factor on the quality minus junk portfolio. This finding show that quality stocks tend to become winner stocks and junk stocks tend to become loosers stocks. By long quality stocks and short quality stocks could have same behaviour with momentum factor.

\section{CONLUSIONS}

This research provides the application of quality factor as investing strategy in Indonesia over 2009-2019. Based on the Asness, Frazzini, and Pedersen (2019) a high-quality firm is one that is profitable, growing, and safe. From each category, we calculate individual z-score and average them to calculate single quality score for every listed companies.

Next, we were constructing 3 portfolios of qualities, consist of quality, junk, and quality minus junk portfolio. We regress each of portfolio with single index model, three factor model by Fama and French, and four factor model by Carhart to obtain the alphas and to observe the abnormal return.

This test shows that quality portfolio consistently produces positive and significant abnormal returns of $1.1 \%-1.2 \%$. In contrary, junk portfolio consistently unable to generate significant abnormal returns. These findings are in line with previous research which show that a quality stock portfolio will provide a significant abnormal return compared to a junk stock portfolio.

However, the results of testing the quality minus the junk portfolio, cannot produce an abnormal return. This differs from the research of Asness, Frazzini, and Pedersen (2018) which proves that the quality minus junk 
strategy can provide a significant abnormal return. One of explanation is due to short selling disincentives from existing regulation.

This research successfully fills the academic gap by determining the same evidence could be achieved by applying same methodology in developing market such as Indonesia. Furthermore, this research has several benefits for the broader investor within Indonesia. First and foremost, we find that one should consider quality of a company to achieve abnormal return when investing in the Indonesian stock market. Secondly, fund managers could create quality stock-based fund or ETF to enable beginner investor to have exposure investing in quality stocks.

\section{REFERENCES}

[1] Altman, E. I. (1968) "Financial Ratios, Discriminant Analysis and The Prediction Of Corporate Bankruptcy," The Journal of Finance, 23(4), hal. 589-609. doi: 10.1111/j.15406261.1968.tb00843.x.

[2] Arbel, A. dan Strebel, P. (1983) "Pay attention to neglected firms!*," The Journal of Portfolio Management, 9(2), hal. 37-42. doi: 10.3905/jpm.1983.408901

[3] Asness, C. S., Frazzini, A. dan Pedersen, L. H. (2019) "Quality minus junk," Review of Accounting Studies, 24(1), hal. 34-112. doi: 10.1007/s11142-018-9470-2.

[4] Banz, R. W. (1981) "The relationship between return and market value of common stocks," Journal of Financial Economics, 9(1), hal. 3-18. doi: 10.1016/0304-405X(81)90018-0.

[5] Black, F., Jensen C., M. dan Scholes, M. (1972) "The Capital Asset Pricing Model: Some Empirical Tests," Studies in the theory of capital markets, hal. 79-121. doi: https://ssrn.com/abstract=908569.

[6] Bodie, Z., Kane, A. dan Marcus, A. J. (2014) Investments 10th Edition, Mc Graw Hill.

[7] Bondt, W. F. M. De dan Thaler, R. (1985) "Does the Stock Market Overreact?," The Journal of Finance, 40(3), hal. 793. doi: 10.2307/2327804.

[8] Campbell, J. Y., Hilscher, J. dan Szilagyi, J. (2008) "In Search of Distress Risk," The Journal of Finance, 63(6), hal. 2899-2939. doi: 10.1111/j.1540-6261.2008.01416.x.

[9] Carhart, M. M. (1997) "On persistence in mutual fund performance," Journal of Finance, 52(1), hal. 57-82. doi: 10.1111/j.1540-6261.1997.tb03808.x.
[10] Fama, E. F. (1970) "Efficient Capital Markets: A Review of Theory and Empirical Work," The Journal of Finance, 25(2), hal. 383. doi: $10.2307 / 2325486$.

[11] Fama, E. F. dan French, K. R. (1993) "Common risk factors in the returns on stocks and bonds," Journal of Financial Economics, 33(1), hal. 3-56. doi: 10.1016/0304-405X(93)90023-5.

[12] Frazzini, A. dan Pedersen, L. H. (2014) "Betting against beta," Journal of Financial Economics, 111(1), hal. 1-25. doi: 10.1016/j.jfineco.2013.10.005.

[13] Gallagher, D. R. et al. (2014) "Quality investing in an Australian context," Australian Journal of Management, 39(4), hal. 615-643. doi: $10.1177 / 0312896213501180$.

[14] George, T. J. dan Hwang, C.-Y. (2010) "A resolution of the distress risk and leverage puzzles in the cross section of stock returns," Journal of Financial Economics, 96(1), hal. 56-79. doi: 10.1016/j.jfineco.2009.11.003.

[15] Graham, B. dan Dodd, D. (1934) Security Analysis. 6th ed.

[16] Greenwald, B. C. et al. (2004) Value Investing: From Graham to Buffett and Beyond. doi: 0471463396.

[17] Gunasekarage, A. dan Wan Kot, H. (2007) "Return-based investment strategies in the New Zealand stock market: momentum wins," Pacific Accounting Review, 19(2), hal. 108-124. doi: $10.1108 / 01140580710819889$.

[18] Hsu, J., Kalesnik, V. dan Kose, E. (2019) "What Is Quality?," Financial Analysts Journal, 75(2), hal. 44-61. doi: 10.1080/0015198X.2019.1567194.

[19] Jegadeesh, N. dan Titman, S. (1993) "Returns to Buying Winners and Selling Losers: Implications for Stock Market Efficiency," The Journal of Finance, 48(1), hal. 65-91. doi: 10.1111/j.15406261.1993.tb04702.x.

[20] Jones, C. P. (2012) Investments: Analysis and Management. Wiley.

[21] Kendall, M. G. dan Hill, A. B. (1953) "The Analysis of Economic Time-Series-Part I: Prices," Journal of the Royal Statistical Society. Series A (General), 116(1), hal. 11. doi: 10.2307/2980947.

[22] Lakonishok, J., Shleifer, A. dan Vishny, R. W. (1993) "Contrarian Investment, Extrapolation, and Risk,” J. Finance, 49(5), hal. 1541-1578.

[23] Lalwani, V. dan Chakraborty, M. (2018) "Quality investing in the Indian stock market," Managerial 
Finance, 44(2), hal. 127-141. doi: 10.1108/MF07-2017-0248.

[24] Lintner, J. (1965) "The Valuation of Risk Assets and the Selection of Risky Investments in Stock Portfolios and Capital Budgets," The Review of Economics and Statistics, 47(1), hal. 13. doi: $10.2307 / 2977249$.

[25] Markowitz, H. (1952) "Portfolio Selection," The Journal of Finance, 7(1), hal. 77. doi: $10.2307 / 2975974$.

[26] Mohanram, P. S. (2005) "Separating Winners from Losers among LowBook-to-Market Stocks using Financial Statement Analysis," Review of Accounting Studies, 10(2-3), hal. 133-170. doi: $10.1007 / \mathrm{s} 11142-005-1526-4$.

[27] Mossin, J. (1966) "Equilibrium in a Capital Asset Market," Econometrica, 34(4), hal. 768. doi: 10.2307/1910098.

[28] Naughton, T., Truong, C. dan Veeraraghavan, M. (2008) "Momentum strategies and stock returns: Chinese evidence," Pacific-Basin Finance Journal, 16(4), hal. 476-492. doi: 10.1016/j.pacfin.2007.10.001.

[29] Ng, C. C. A. dan Shen, J. (2020) "Quality investing in Asian stock markets," Accounting and Finance, 60(3), hal. 3033-3064. doi: 10.1111/acfi.12446.

[30] Novy-Marx, R. (2013) "The other side of value: The gross profitability premium," Journal of Financial Economics, 108(1), hal. 1-28. doi: 10.1016/j.jfineco.2013.01.003.

[31] O’Brien, M. A., Brailsford, T. dan Gaunt, C. (2010) "Interaction of size, book-to-market and momentum effects in Australia," Accounting \& Finance, 50(1). doi: 10.1111/j.1467629X.2009.00318.x.

[32] Ohlson, J. A. (1980) "Financial Ratios and the Probabilistic Prediction of Bankruptcy," Journal of Accounting Research, 18(1), hal. 109. doi: $10.2307 / 2490395$.

[33] Penman, S. H., Richardson, S. A. dan Tuna, İ. (2007) "The Book-to-Price Effect in Stock Returns: Accounting for Leverage," Journal of Accounting Research, 45(2), hal. 427-467. doi: 10.1111/j.1475-679X.2007.00240.x.

[34] Piotroski, J. D. (2000) "Value Investing: The Use of Historical Financial Statement Information to Separate Winners from Losers," Journal of Accounting Research, 38. doi: 10.2307/2672906.

[35] Richardson, S. A. et al. (2005) "Accrual reliability, earnings persistence and stock prices," Journal of
Accounting and Economics, 39(3), hal. 437-485. doi: 10.1016/j.jacceco.2005.04.005.

[36] Sharpe, W. F. (1963) “A Simplified Model for Portfolio Analysis," Management Science, 9(2), hal. 277-293. doi: 10.1287/mnsc.9.2.277.

[37] Sharpe, W. F. (1964) "Capital Asset Prices: A Theory of Market Equilibrium under Conditions of Risk," The Journal of Finance, 19(3), hal. 425. doi: $10.2307 / 2977928$.

[38] Sloan, R. G. (1996) "Information in Accruals and Cash Flows About Future Earnings ?," 71(3), hal. 289-315.

[39] Stiglitz, J. E. dan Grossman, S. J. (1980) “On the Impossibility of Informationally Efficient Markets," American Economic Review, hal. 393408.

[40] Treynor, J. L. (1961) "Market Value, Time, and Risk."

[41] Treynor, J. L. (1962) “Toward A Theory of Market Value of Risky Assets." 